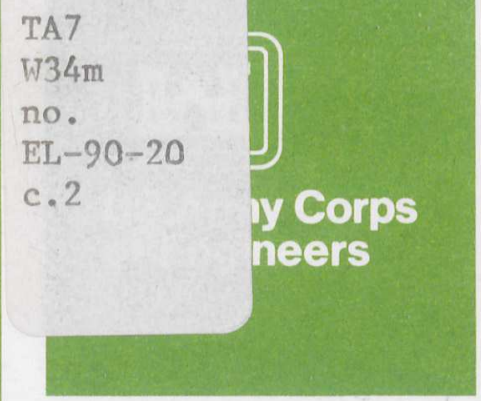

\title{
ASSESSMENT OF DREDGED MATERIAL TOXICITY IN SAN FRANCISCO BAY
}

\author{
by \\ Thomas M. Dillon, David W. Moore \\ Environmental Laboratory \\ DEPARTMENT OF THE ARMY \\ Waterways Experiment Station, Corps of Engineers \\ 3909 Halls Ferry Road, Vicksburg, Mississippi 39180-6199

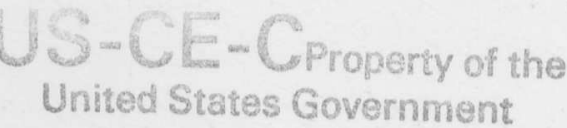

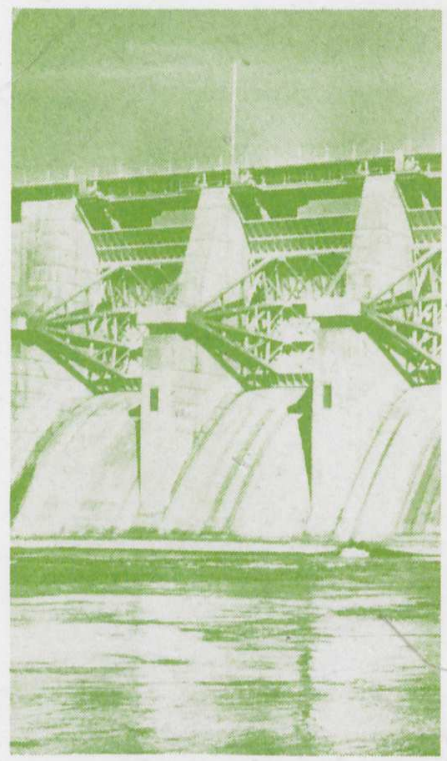

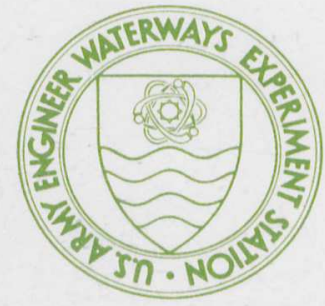

November 1990

Final Report

Approved For Public Release; Distribution Unlimited

RESEARCH LIERARY

US ARMY ENCINEER WATERWAYS

EYPERWWENT STATION

VICKSBURG, MISSISSIPPI

Prepared for US Army Engineer District, San Francisco San Francisco, California 94105-1905 
Destroy this report when no longer needed. Do not return it to the originator.

The findings in this report are not to be construed as an official Department of the Army position untess so designated by other authorized documents.

The contents of this report are not to be used for advertising, publication, or promotional purposes. Citation of trade names does not constitute an official endorsement or approval of the use of such commercial products. 
Public reporting burden for this collection of information is estimated to average 1 hour per response, including the time for reviewing instructions, searching existing data sources, gathering and maintaining the data needed, and completing and reviewing the collection of information. Send comments regarding this burden estimate or any other aspect of this collection of information, including suggestions for reducing this burden, to Washington Headquarters Services. Directorate for Information Operations and Reports, 12,15
Davis Highway, Suite 1204. Arlington, VA 22202-4302, and to the Office of Management and 8udget, Paperwork Reduction Project (0704-0188), Washington, DC 20503.

\begin{tabular}{|l|l|l|}
\hline 1. AGENCY USE ONLY (Leave blank) & 2. REPORT DATE & 3. REPORT TYPE AND DATES COVERED
\end{tabular} November 1990 Final report

A. TITLE AND SUBTITLE

San Francisco Bay

\section{AUTHOR(S)}

Thomas M. Dillon, David W. Moore

\section{PERFORMING ORGANIZATION NAME(S) AND ADDRESS(ES)}

8. PERFORMING ORGANIZATION REPORT NUMBER

USAE Waterways Experiment Station, Environmental Laboratory, 3909 Halls Ferry Road, Vicksburg, MS, 39180-6199

9. SPONSORING/MONITORING AGENCY NAME(S) AND ADDRESS(ES)

USAE District, San Francisco, San Francisco, CA $94105-1905$
Miscellaneous Paper EL-90-20

10. SPONSORING/MONITORING AGENCY REPORT NUMBER

\section{SUPPLEMENTARY NOTES}

Available from National Technical Information Service, 5285 Port Royal Road, Springfield, VA 22161

12a. DISTRIBUTION/AVAILABILITY STATEMENT

12b. DISTRIBUTION CODE

Approved for public release; distribution unlimited

\section{ABSTRACT (Maximum 200 words)}

This report is designed to address concerns regarding the potential toxicity of dredged material from San Francisco Bay and to provide input into the San Francisco District's Long-Term Management Strategy for dredged material disposal. To this end, a review of the regulatory history of dredged material management within San Francisco Bay and the development of sediment toxicity tests to assess dredged material is provided. Included in this discussion is a national overview of sediment toxicity, as well as the toxicity of San Francisco Bay sediments. Information gaps are identified and prioritized. Finally, specific research hypotheses are posed that will allow selected technical questions to be addressed by direct experimental examination.

$\begin{aligned} & \text { 14. SUBJECT TERMS } \\
& \text { Chronic sublethal } \\
& \text { Noncontaminant effects }\end{aligned}$
\begin{tabular}{l|l} 
17. SECURITY CLASSIFICATION \\
$\begin{array}{l}\text { OF REPORT } \\
\text { UNCLASSIFIED }\end{array}$ & $\begin{array}{l}\text { 18. SECURITY CLASSIFICATION } \\
\text { OF THIS PAGE } \\
\text { UNCLASSIFIED }\end{array}$ \\
\hline NSN 7540-01-280-5500 &
\end{tabular}




\section{PREFACE}

This report was prepared for the US Army Engineer District, San Francisco, by the US Army Engineer Waterways Experiment Station (WES), Environmental Laboratory (EL). The objective of the report was to identify what is known regarding San Francisco dredged material toxicity. It was also intended to identify information gaps and what additional scientific information was needed to fill those gaps. In a larger sense, this document was intended to provide input to the District's Disposal Management Plan and Long-Term Management Strategy for dredged material disposal in the San Francisco Bay area.

Financial support for preparation of this report was provided by the San Francisco District through an Intra-Army Order for Reimbursable Services. The authors gratefully acknowledge the technical support and reviews provided by Dr. Thomas Wakeman, Ms. Sandra Lemlich, Mr. Brian Walls, and Mr. Thomas Chase of the San Francisco District.

This report was prepared by Drs. Thomas M. Dillon and David W. Moore of the Ecosystem Research and Simulation Division (ERSD), EL. The work was performed under the general supervision of Dr. Lloyd H. Saunders, Chief, Contaminant Mobility and Regulatory Criteria Group. Chief of ERSD was Mr. Donald L. Robey; Chief of EL was Dr. John Harrison.

Commander and Director of WES was COL Larry B. Fulton, EN. Technical Director was Dr. Robert W. Whalin.

This report should be cited as follows:

Dillon, Thomas M., and Moore, David W. 1990. "Assessment of Dredged Material Toxicity in San Francisco Bay, " Miscellaneous Paper EL-90-20, US Army Engineer Waterways Experiment Station, Vicksburg, MS. 
PREFACE

CONVERSION FACTORS, NON-SI TO SI (METRIC) UNITS

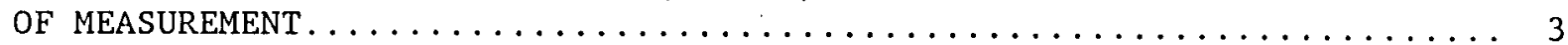

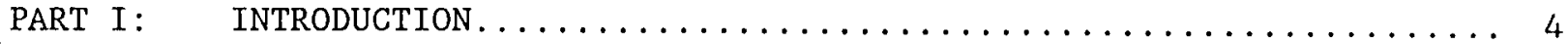

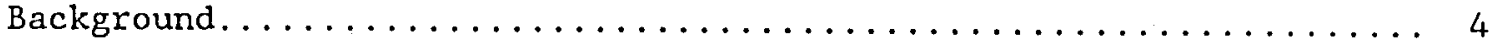

Scope.................................. 5

Regulatory History of Dredged Material Management in

San Francisco Bay.............................. 5

Overview of Sediment Toxicity Test Development in the

United States........................... 8

PART II: ASSESSING THE POTENTIAL TOXICITY OF SAN FRANCISCO BAY

SEDIMENTS . . . . . . . . . . . . . . . . . 12

Noncontaminant-Related Toxicity Potential................. 12

Toxicity of Sediment-Associated Trace Contaminants............. 16

PART III: DEVELOPMENT OF CHRONIC SUBLETHAL SEDIMENT BIOASSAYS ....... 23

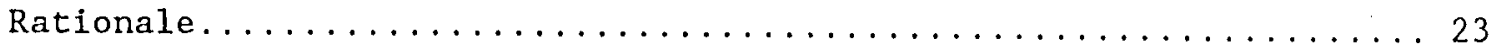

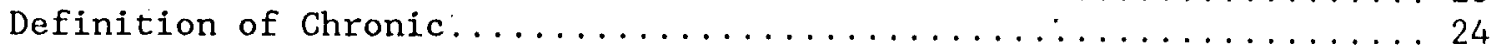

Potential Bias from Nontreatment Effects................... 24

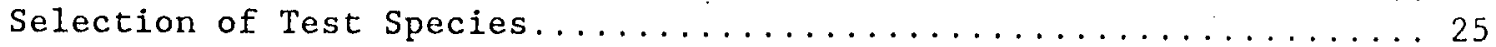

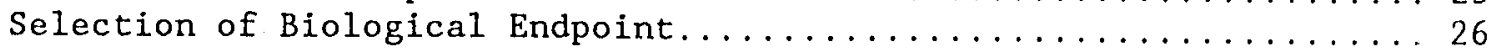

Development of Interpretive Guidance.................... 28

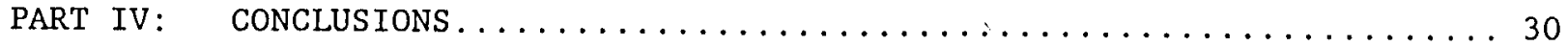

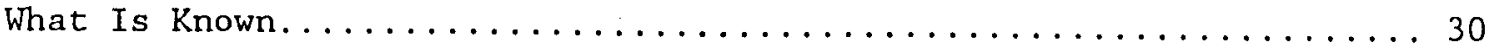

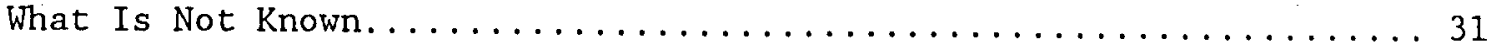

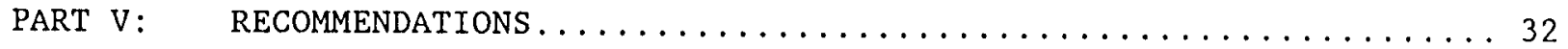

PART VI: HYPOTHESES FOR EVALUATING SEDIMENT TOXICITY............ 33

Routine Regulatory Testing....................... 33

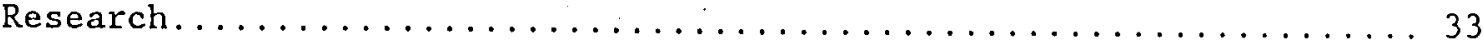

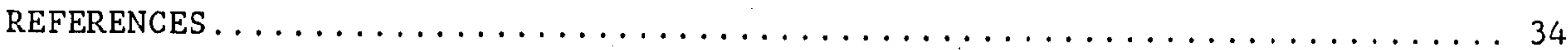




\section{CONVERSION FACTORS, NON-SI TO SI (METRIC) \\ UNITS OF MEASUREMENT}

Non-SI units of measurement used in this report can be converted to SI (metric) units as follows:

Multiply

cubic yards

fathoms

$\frac{\mathrm{By}}{0.7645549}$
1.8288

To Obtain

cubic meters

meters 
PART I: INTRODUCTION

\section{Background}

San Francisco Bay is a highly altered estuary. Two of the major reasons are the loss of wetlands and the reduction in freshwater inflow. About 958 of all freshwater/estuarine marshlands have been lost to land reclamation before 1850. The amount of freshwater flowing into San Francisco Bay in 1980 had been reduced by 608 . This reduction is projected to increase to 708 by the year 2000 (Nichols et al. 1986). It is not surprising, therefore, that the estuary has experienced general decline in health and viability. One of the more noticeable symptoms of this decline has been the gradual loss of biological resources such as the striped bass and Pacific herring fisheries.

An increase in the input of environmental contaminants has accompanied the physical alterations to San Francisco Bay. Major pollutant sources include the freshwater inflow from the Sacramento-San Joaquin River systems, over 50 waste treatment plants and about 200 industries which are permitted to discharge directly into the Bay (Luoma and Phillips 1988). Environmental contaminants discharged into aqueous systems tend to associate with particulate material in the water column and with consolidated bedded sediments. Periodically, these bedded sediments must be removed to maintain navigable waterways. There is a real concern within the San Francisco Bay community that the relocation of these dredged materials may be having unacceptable adverse impacts on aquatic biota.

The amount of sediment dredged each year in San Francisco Bay is not small. Approximately 7 million cubic yards* (mcy) of sediment from Federal projects and permit actions are relocated annually. This value is surprisingly close to the estimated average annual sediment inflow into San Francisco Bay, 8-10.5 mcy (USACE 1979). It has been estimated that 3.9-5.2 mcy of material leaves the Bay annually while Central, and North Bays experience a combined net accumulation of $5.5 \mathrm{mcy}$ (USACE 1979). South Bay shows a net loss of

* A table of factors for converting non-SI units of measurement to SI (metric) units is presented on page 3 . 
nearly 1 mcy per year (Krone 1979). Despite these large numbers, the greatest yearly source of suspended sediment in San Francisco Bay is the resuspension of existing material. Approximately 160-170 mcy of sediment are resuspended each year by wind waves and currents (USACE 1979). Here too is a concern that these resuspended sediments and associated trace contaminants are having a toxic effect on fish and aquatic invertebrates.

\section{$\underline{\text { Scope }}$}

To address the concerns that dredged material in San Francisco Bay is exerting toxic effects on biota, this report will focus on what is known regarding sediment toxicity. To provide the necessary historical perspective, the manner in which dredged material has been evaluated and managed in San Francisco Bay will first be reviewed. Next, advances in the state-of-theart/state-of-the-practice for assessing sediment toxicity will be reviewed. This will include a national overview as well as sediment toxicity of San Francisco Bay sediments. The foregoing will identify what is known and thus, what is not known. These informational gaps will be prioritized. Finally, specific research hypotheses will be posed which will allow selected technical questions to be tested and answered by direct experimentation.

This report is also intended to provide input into the San Francisco District's Long Term Management Strategy for dredged material disposal.

\section{Regulatory History of Dredged Material Management in San Francisco Bay}

To help define what is known regarding the potential toxicity of San Francisco Bay sediments, it is useful to first examine how dredged material has been regulated in the past. Important milestones in that process are shown in Table 1. It was recognized very early that San Francisco Bay is a physically dynamic system and that most dredged material disposal sites were dispersive. Consequently, initial management concerns were mostly operational. That is, efforts were directed towards optimizing dredging and disposal operations to minimize transportation costs and redredging.

Passage of the National Environmental Policy Act in 1970 outlined the Federal government's policy toward the environment and signaled an increasing awareness of environmental protection in this country. That same year the 
Table 1

Milestones in the Regulation of Dredged Material in San Francisco Bay

1965 - Committee on Tidal Hydraulics suggests CESPN may be redredging a significant amount of material.

1970 - Passage of the National Environmental Policy Act.

1970 - CESPN initiates Dredged Disposal Study. Terminated in 1975.

1972 - CESPN reduces the number of in-bay disposal sites from 11 to 5.

1972 - California RWQCB adopts USEPA's Jensen bulk sediment criteria. Material classified as "polluted" by these criteria was either placed upland or taken offshore to the 100-fathom ocean disposal site.

1973 - USACE initiates Dredged Material Research Program (DMRP). Terminated in 1978.

1977 - Publication of USEPA/USACE Ocean Dumping Implementation Manual.

1978 - PN 78-1 issued by CESPN. Elutriate test procedures adopted from the Ocean Dumping Implementation Manual and in-bay disposal limited to 3 dispersive sites (Alcatraz, San Pablo Bay and Carquinez Strait).

1980 - California RWQCB adopts PN 78-1.

1980 - 100-fathom ocean disposal site becomes part of the Point Reyes-Farallon Islands Marine Sanctuary and is subsequently removed from the final designation process by USEPA.

1982 - Mounding at the Alcatraz site noted in November.

1984 - CESPN implements slurry policy to enhance dispersion during disposal.

1985 - CESPN establishes the Disposal Management Program (DMP) to find operational solutions to disposal problems which are environmentally acceptable.

1985 - San Francisco Bar Channel ocean disposal site receives final designation by USEPA. It can receive only coarse grained material.

1987 - PN 87-1 issued jointly by CESPN, California RWQCB and USEPA Region IX.

1988 - Bioassay procedures in PN 87-1 used to evaluate Inner Oakland Harbor sediments.

1989 - DMP reconfigured to reflect increasing environmental concerns in San Francisco Bay.

1990 - Revision of USEPA/USACE Ocean Dumping Implementation Manual. 
US Army Corps of Engineers (USACE) San Francisco District (CESPN) initiated the Dredged Disposal Study (DDS) (USACE 1977). The DDS was a multifaceted interdisciplinary study designed, in part, to address some of the environmental concerns regarding potential impacts of dredging operations. Although sediment toxicity was not examined directly the physical impacts on biota (USACE 1975b) and the bioaccumulation of contaminants from dredged material was evaluated in laboratory and field studies (USACE 1975c, USACE 1975d). Those studies demonstrated:

1) Estuarine animals can survive suspended sediment loads in excess of those normally encountered during dredging and disposal.

2) In laboratory exposures to San Francisco Bay sediments estuarine animals can bioaccumulate trace contaminants.

3) In field studies, contaminant tissue concentrations in animals near the disposal operations were not different from those far removed. The one exception was slightly elevated $p, p^{\prime}-D D E$ concentrations in mussels, Mytilus edulis, during disposal. These differences were not detected one month post-disposal.

In 1972, the California Regional Water Quality Control Board (RWQCB) adopted the Jensen criteria. These numerical criteria were developed by the US Environmental Protection Agency (USEPA) for freshwater sediment in the Great Lakes and classified sediment as highly polluted, moderately polluted or non-polluted based on bulk sediment chemistry. As research on dredged material progressed it became clear that these and other chemically-based numerical criteria were technically inadequate because they did not assess either bioaccumulation potential or toxicity. Both assessments were evaluated in bioassay procedures contained in the USEPA/USACE Ocean Dumping Implementation Manual (1977).

CESPN adopted the use of bioassays for evaluating dredged material. Regulatory procedures were outlined in Public Notice (PN) 78-1. Elutriate procedures were emphasized since disposal sites in San Francisco Bay were generally dispersive. PN 78-1 also reduced the number of disposal sites from 5 to 3. These were located in the Carquinez Strait, San Pablo Bay and Alcatraz Island. To facilitate net export out of the Bay under the Golden Gate Bridge most dredged material was taken to the Alcatraz disposal site.

In 1982, shoaling was noted at the Alcatraz site. As a result of this important development the CESPN took several steps. They instituted a slurry policy to enhance dispersion during disposal. They greatly reduced the amount of new dredged material taken to the Alcatraz site and even. removed 30 tons of construction debris from the site. They monitored the physical configuration 
of the mound at Alcatraz and found it to be stable after two winter seasons. All of these actions lead to the conclusion that the Alcatraz site could not be considered fully dispersive. Since the majority of dredged material in San Francisco Bay was taken to Alcatraz, a reduction in the capacity of that site represented a major impediment to maintenance dredging and to anticipated new work activities. CESPN formed the Disposal Management Program (DMP) in 1985 and charged it with finding solutions to the disposal problem.

In 1987, CESPN, RWQCB and USEPA Region IX jointly issued PN 87-1. This notice outlined new evaluative procedures for dredged material which reflected advances in the scientific community and the fact that San Francisco Bay disposal sites might not be fully dispersive. For example, there was an increased emphasis on solid phase bioassays as opposed to water column evaluations (i.e., the elutriate procedure). Ten years of elutriate testing in San Francisco Bay had shown the potential for water column impacts associated with disposal operations were minimal to non-existent. Similarly, it was shown during the DMRP that if dredged material was going to impact the environment those effects would most likely be associated with the benthic community. Procedures in PN 87-1 generally follow those found in the USEPA/USACE Ocean Dumping Implementation Manual. The first major application of these procedures was the proposed dredging of Oakland Inner Harbor (see Acute toxicity bioassays, $p 18$, for details).

The DMP was reconfigured in 1989 to address increasing environmental concerns and to reflect CESPN's commitment to a Long Term Management Strategy for dredged material. The following year the Ocean Dumping Implementation Manual was revised to reflect 13 years of regulatory experience and the many scientific advances that had occurred since 1977.

\section{Overview of Sediment Toxicity Test Development in the United States}

As indicated in the foregoing discussion, the regulation of dredged material in San Francisco Bay has taken advantage of scientific advancements which have taken place elsewhere in the United States. To address concerns specific to the potential toxicity of San Francisco Bay sediments it is important to have some general knowledge of advances in the field of sediment ecotoxicology. The following is not intended to be a comprehensive review 
per se, rather it is meant to provide the reader a general sense of the advances which have occurred over the past 20 years.

The first peer-reviewed journal article which reported an attempt to assess sediment toxicity was published in 1971 by Gannon and Beeton. The laboratory procedures involved exposing amphipods to freshwater dredged material which had been placed in modified milk cartons. In 1973, recognizing the need for a strong technical base in its regulatory program, the USACE initiated the Dredged Material Research Program (DMRP). Included in the scope of this large program was the development of elutriate and solid phase bioassays to assess potential water column and benthic impacts, respectively (Saucier et al. 1978). The bioassays developed during the DMRP were subsequently incorporated into the Ocean Dumping Implementation Manual jointly published by USEPA and USACE in 1977. These sediment bioassays represented a balance between the state-of-the-art and what could be routinely conducted in a regulatory program.

Prior to the mid-70's, the scientific community expressed relatively little interest in sediment toxicity. Most of their energies were focused on the fate and effects of environmental contaminants dissolved in aqueous solutions. After the Priority Pollutant List was published in 1976 that emphasis shifted. There were two reasons for this change.' One, it was discovered that many of the chemicals on the Priority Pollutant List were not very water soluble. Second, as more field data was gathered it became apparent that concentrations of many contaminants on the Priority Pollutant List were much higher in the sediment than in the overlying water. Those findings lead to initial speculation that sediments might be extremely toxic. However, subsequent research showed that the same forces causing chemicals to partition into the sediments also restricted their bioavailability to aquatic organisms.

A major milestone marking these scientific advances was the $6^{\text {th }}$ Pellston Conference held in 1984 (Dickson et al. 1984). This was the first time leaders in the scientific community formally met to discuss the fate and effects of sediment-associated contaminants. Bioassay procedures contained in the 1977 USEPA/USACE Ocean Dumping Implementation Manual formed the basis for initial discussion. The researchers reached consensus regarding sediment toxicity (Anderson et al. 1984). They recognized that species sensitivity was related, in part, to the degree of contact between sediment and organism. They recommended amphipods and mysid shrimp for lethal tests and polychaetes, 
bivalves, oligochaetes and fish for behavioral or sublethal tests. There was also a strong endorsement of the Tiered Testing Approach for evaluating contaminated sediments. This approach eliminates unnecessary testing and directs limited resources to solving more urgent problems.

Another important milestone in the evolution of sediment toxicity methods occurred in 1987. Members of the American Society for Testing and Materials (ASTM) created a new Subcommittee, E47.01 Sediment Toxicology. This Subcommittee was charged with identifying technically sound procedures for evaluating sediment toxicity and with drafting appropriate standardized guideline documents. The draft protocols, which are in various states of preparation, include:

1) Solid Phase Toxicity Tests With Freshwater Invertebrates

2) Solid Phase Toxicity Tests With Marine Amphipods

3) Solid Phase Toxicity Tests With Marine Polychaetes

4) Solid Phase Bioaccumulation Tests With Invertebrates

5) Solid Phase Bioaccumulation Tests With Fish

6) Guidance For Designing Sediment Toxicity Tests

7) Guidance For Collection, Storage, Characterization and Manipulation of Sediment to Toxicity Testing

When the USEPA/USACE Ocean Dumping Implementation Manual was first published in 1977 the procedures it contained represented a balance between the state-of-the-art and what could be practically achieved in a routine regulatory testing environment. It was realized at that time that revisions would have to be made to reflect anticipated advances in the scientific community as well as experience gained in regulatory testing programs. The Manual has recently (1990) been revised. Significant improvements to the current Manual as they relate to sediment toxicity evaluations include:

1) Formalizing the Tiered Testing Approach

2) Refinements to the Species Selection Process

3) Provisions for Evaluating Chronic Sublethal Effects

The assessment of chronic sublethal effects is treated as a Tier IV assessment and would be carried out only if there is a reason to believe chronic impacts may be occurring and if technically sound test protocols are available. 
Table 2

Milestones in the Scientific Development of Sediment Toxicity Tests

1971 - Gannon and Beeton published first journal article on sediment bioassays.

1973 - USACE initiates Dredged Material Research Program (DMRP). Terminated in 1978.

1976 - Publication of Priority Pollutant List by USEPA.

1977 - Publication of USEPA/USACE Ocean Dumping Implementation Manual.

1984 - Pellston Conference on Fate and Effect of Sediment-Bound Chemicals.

1987 - Formation of ASTM Subcommittee E47.03 on Sediment Toxicology.

1990 - Revision of USEPA/USACE Ocean Dumping Implementation Manual. 
PART II: ASSESSING THE POTENTIAL TOXICITY OF SAN FRANCISCO BAY SEDIMENTS

Noncontaminant-Related Toxicity Potential

There is a concern that during the relocation of dredged material within San Francisco Bay chemical impacts not associated with trace contaminants may be adversely affecting indigenous biota. Often cited as potential problems are elevated ammonia and sulfides and depressed oxygen concentrations (hypoxia). An assessment of the potential impact of each of these is provided below.

Ammonia

Ammonia is a commonly occurring chemical that can exert toxicity at relatively low concentrations on fish and other aquatic organisms. Its presence in the environment may arise from inputs such as sewage effluent, industrial waste, agricultural run-off and as a naturally occurring metabolic by-product. In an aqueous solution, ammonia is present in both a gaseous or unionized form (known as ammonia or $\mathrm{NH}_{3}$ ) and in an ionized form (known as the ammonium ion or $\mathrm{NH}_{4}^{+}$).

The toxicity of aqueous ammonia solutions is primarily due to the unionized form of the chemical (Wuhrman and Woker 1948). Therefore, those factors controlling the equilibrium constant (i.e., $\mathrm{pH}$, temperature, and ionic strength) will have significant influence on ammonia toxicity potential. The percent. of total ammonia present in the unionized form is significantly affected by factors such as $\mathrm{pH}$, temperature, and to a lesser degree the ionic strength of the solution (e.g. hardness or salinity) (Thurston et al. 1981b, Alabaster et al. 1979, Emerson et a1. 1975, Whitfield 1974, Skarheim 1973). At near neutral pH's (7.0-7.8) typical of seawater, 0.28 to 5.08 of total ammonia occurs in the unionized form (Emerson et al. 1975).

There are a number of methods for the direct determination of total ammonia concentrations in water. For manual analysis of low concentrations ( 0.02 to $5.00 \mathrm{mg} \mathrm{NH}-\mathrm{N} / \mathrm{L}$ ) in drinking water, natural water, or highly purified waste water, the colorimetric Nessler Method is recommended. The Phenate Method, another colorimetric procedure, offers similar sensitivity $(0.01$ to $0.50 \mathrm{mg} \mathrm{NH}-\mathrm{N} / \mathrm{L}$ ) and can be used in automated analysis. However, this method is subject to potential interferences due to alkalinity, color, and/or turbidity. Finally, an ammonia-selective electrode procedure is useful for concentrations which may range from 0.03 to $1400 \mathrm{mg} \mathrm{NH}_{3}-\mathrm{N} / \mathrm{L}$ (APHA 1989). 
Exposures of teleosts to elevated environmental levels of ammonia have been found to result in degenerative gill and kidney damage (Burrows 1964, Smart 1976, Thurston et al. 1978), reduced growth rates (Burrows 1964, Colt and Tchobanoglous 1978, Robinette 1976), reduced $\mathrm{O}_{2}$ carrying capacity of the hemoglobin (Sousa and Meade 1977), increased urine output (Lloyd and Orr 1969) and the release of corticosteroid hormones (Tomasso et al. 1980). Additional research has indicated low dissolved oxygen enhances the toxicity of ammonia (Merkens and Downing 1957, Thurston et al. 1981a, Lloyd 1961).

Concentrations of unionized ammonia reported to be acutely toxic to freshwater invertebrates range from 0.53 to $22.8 \mathrm{mg} / \mathrm{L} \mathrm{NH}_{3}$. Studies conducted with freshwater fish species indicate acute toxicity ranging from 0.083 to $4.2 \mathrm{mg} / \mathrm{L} \mathrm{NH}_{3}$. The majority of these tests were conducted with salmonids which are the most sensitive of the fish species tested. Chronic studies indicate concentrations ranging from 0.0017 to $0.612 \mathrm{mg} / \mathrm{L}-\mathrm{NH}_{3}$ for fish species tested and from 0.3 to $1.2 \mathrm{mg} / \mathrm{L} \mathrm{NH}_{3}$ for freshwater cladocerans (USEPA 1985).

There is very little data on the toxicity of ammonia to saltwater species. The few studies conducted indicate that saltwater species are, in general, more sensitive to ammonia than freshwater species. Acute toxicity values for saltwater organisms range from 0.38 to $37.0 \mathrm{mg} / \mathrm{L}$ for the invertebrates tested and 0.47 to $2.38 \mathrm{mg} / \mathrm{L}$ for fish. There are no chronic values for saltwater species (USEPA 1985).

Environmental levels of $\mathrm{NH}_{3}$ have been shown to potentially affect toxicity observed in sediment bioassays conducted in the laboratory. A study by Jones and Lee (1988) found elutriates of sediment from New York released sufficient ammonia to produce toxicity in grass shrimp, Palaemonetes pugio $(96 \mathrm{~h} \mathrm{LC50}=0.3-0.5 \mathrm{mg} / \mathrm{L})$. The authors suggested that toxicity observed in elutriates with sediments from other waterways might also be due to elevated levels of ammonia as well as trace contaminants. Similar results were reported for freshwater sediments from the lower Fox River/Green Bay system by Ankley et al. (Ankley et al. 1990). In the San Francisco Bay area a dredge disposal study indicated water levels of ammonia rose only very slightly from 0.05-0.15 mg/L $\mathrm{NH}_{3}$ one month prior to disposal to $0.05-0.30 \mathrm{mg} / \mathrm{L} \mathrm{NH}_{3}$ during disposal (USACE 1975a). These concentrations do not appear to represent any potential for ammonia toxicity when compared to the acute toxicity concentrations for saltwater organisms published by USEPA (1985).

Based on the toxicity of ammonia to freshwater organisms European Inland Fisheries Advisory Commission (1970) recommends a criterion of $0.025 \mathrm{mg} / \mathrm{L} \mathrm{NH}_{3}$ 
at a temperature above $5^{\circ} \mathrm{C}$ and below a $\mathrm{pH}$ of 8.5 . The USEPA recommends a site specific criterion that can be used to calculate acceptable $1 \mathrm{~h}$ or $4 \mathrm{~d}$ average $\mathrm{NH}_{3}$ concentrations based on specific $\mathrm{pH}$ and temperature conditions with salmonids and other coldwater species present or absent. Based on this criterion the $1 \mathrm{~h}$ average concentration not to be exceeded with salmonids present at a temperature of $20^{\circ} \mathrm{C}$ and a $\mathrm{pH}$ of 7.5 would be $0.181 \mathrm{mg} / \mathrm{L} \mathrm{NH}_{3}$ while the $4 \mathrm{~d}$ average not to be exceeded would be $0.0181 \mathrm{mg} / \mathrm{L} \mathrm{NH}_{3}$ (USEPA 1985). Hydrogen sulfide

Hydrogen sulfide is produced by the bacterial reduction of sulfates and the putrefaction of proteins. It is often associated with low dissolved oxygen concentrations (Theede 1973). Sewage, naturally decomposing organic matter, and some industrial wastes (i.e. effluent from tanneries, pulp mills, chemical plants) are major sources of sulfides (USEPA 1976). Hydrogen sulfide is a metabolic poison that is lethal at concentrations less than $1 \mathrm{mg} / \mathrm{L}$ to most fish (Boon and Follis 1967, Colby and Smith 1967, Smith et al. 1976) and many invertebrates as wel1 (Oseid and Smith 1974). In an aqueous solution, hydrogen sulfide exists in three forms: $\mathrm{H}_{2} \mathrm{~S}, \mathrm{HS}^{-}$, and $\mathrm{S}^{*}$. As with ammonia, the relative proportion of these three forms depends on $\mathrm{pH}$, temperature, and salinity (Millero et al. 1988). The concentration of $\mathrm{H}_{2} \mathrm{~S}$ is also strongly affected by dissolved oxygen concentrations (i.e. oxygen rapidly oxidizes sulfide to either $\mathrm{S}^{\circ}$ or $\mathrm{SO}_{4}$ ). The toxicity of hydrogen sulfide is thought to be a result of the undissociated $\mathrm{H}_{2} \mathrm{~S}$ molecule (NRC 1979, Pearson and Rosenberg 1978). The interaction between dissociation and hypoxia makes the creation of stable exposure concentrations in the laboratory difficult. It also confounds interpretation of effects data since discriminating hypoxic effects from those due to $\mathrm{H}_{2} \mathrm{~S}$ is problematic.

There are a number of methods for measuring total sulfide concentrations in water. An iodometric titration is recommended for freshly collected samples free of interferences with concentrations of sulfide greater than $1 \mathrm{mg} / \mathrm{L}$. A colorimetric procedure known as the Methylene Blue Method allows for the short term storage of samples prior to analysis and is useful for samples containing from 0.1 to $20 \mathrm{mg} / \mathrm{L}$ total sulfides. There is also a potentiometric method that utilizes a silver electrode and a reference electrode to estimate the concentration of total sulfides (APHA 1989).

Hydrogen sulfide exerts its toxicity by forming sulfides with the active groups of different enzymes. For example, the iron in cytochrome oxidase is tied up as a sulfide, thereby interrupting cellular respiration.. In addition, 
a decrease in the redox potential associated with $\mathrm{H}_{2} \mathrm{~S}$ may inhibit oxidizing reactions (Theede 1973). A few organisms, primarily benthic invertebrates, are extremely tolerant of $\mathrm{H}_{2} \mathrm{~S}$. Several investigators have shown that some benthic species will chose a sulfidic habitat over other habitats (Meyers et al. 1988, Powell et al. 1979). Other animals are able to tolerate sulfidic conditions for short periods of time (Theede et al. 1969, Baird et al. 1973). Many of these animals have been shown to possess adaptive mechanisms to exclude or detoxify $\mathrm{H}_{2} \mathrm{~S}$ (Powell et al. 1979, Arp and Childress 1983, Powell and Somero 1983). Decreasing pH, dissolved oxygen, and/or increasing temperature may act to enhance the toxicity of $\mathrm{H}_{2} \mathrm{~S}$ (Theede 1973, USEPA 1976).

Most of the available data indicates acute toxicity occurs at water concentrations greater than $0.5 \mathrm{mg} / \mathrm{L}$ total sulfides (Boon and Follis 1967, and Theede et al. 1969, Main and Nelson 1988). Chronic effects data suggest that exposure to much lower levels of total sulfides $(0.001$ to $0.050 \mathrm{mg} / \mathrm{L})$ will result in toxicity (Adelman and Smith 1970, Smith and Oseid 1972, USEPA 1976). The USEPA (1976) suggests that concentrations greater thain $0.002 \mathrm{mg} / \mathrm{L}$ undissociated $\mathrm{H}_{2} \mathrm{~S}$ constitute a long-term hazard to most fish and other aquatic life.

Levels of hydrogen sulfide commonly found in anaerobic soft bottom sediments range from 1 to $300 \mathrm{mg} / \mathrm{L}$ total sulfides (Berner 1963, Howarth et al. 1983). Just above the sediment surface, concentrations may be much lower; $0.02-0.10 \mathrm{mg} / \mathrm{L}$ (Colby and Smith 1967). In the San Francisco Bay area, sediment sulfide concentrations were found to range from 0 to $730 \mathrm{mg} / \mathrm{kg}$ wet weight total sulfides (USACE 1975). However, interstitial concentrations of the toxicologically important sulfide, $\mathrm{H}_{2} \mathrm{~S}$, were below detection $(<0.05 \mathrm{mg} / \mathrm{L})$. This is because unionized sulfide in interstitial water quickly forms insoluble complexes with iron before building up to measurable quantities.

Hypoxia

In the environment, elevated levels of unionized ammonia and undissociated $\mathrm{H}_{2} \mathrm{~S}$ are often accompanied by low dissolved oxygen concentrations (hypoxia). Furthermore, low dissolved oxygen may exacerbate the toxicity of these compounds.

Both temperature and salinity have a significant effect on solubility of oxygen. As temperature increases the solubility of $\mathrm{O}_{2}$ decreases. For example, at 1 atmosphere and $10^{\circ} \mathrm{C}$ the concentration at which there is 1008 saturation is $11.27 \mathrm{mg} 0_{2} / \mathrm{L}$ while at $20^{\circ} \mathrm{C}$ the level of saturation is only $9.07 \mathrm{mg} / \mathrm{L}$. Similarly as salinity increases the solubility of $0_{2}$ decreases. At 1 atmosphere and $20^{\circ} \mathrm{C}$ the level of saturation in freshwater is $9.07 \mathrm{mg} / \mathrm{L}$ while at a 
salinity of 20 parts per thousand the level of saturation is $7.20 \mathrm{mg} / \mathrm{L}$ (Vernberg and Vernberg 1970).

In general, organisms from high oxygen environments (e.g. coldwater gamefish) are likely to have higher $\mathrm{O}_{2}$ consumption rates and be less tolerant of low oxygen conditions. Conversely, organisms from low oxygen environments (e.g., many benthic invertebrates) have lower $O_{2}$ consumption and are more tolerant of low oxygen conditions. Many animals regulate their metabolism and maintain constant $\mathrm{O}_{2}$ consumption until environmental $\mathrm{O}_{2}$ reaches some critical tolerance level at which point their $\mathrm{O}_{2}$ consumption rapidly declines (ocyregulators). Other organisms can be described as metabolic conformers with their $\mathrm{O}_{2}$ consumption rates varying according to the level of environmental $\mathrm{O}_{2}$ (oxyconformers). In general, those organisms more tolerant of low oxygen conditions tend to be metabolic conformers (Prosser 1973).

As part of good laboratory practice, it is generally recommended that concentrations of dissolved oxygen should remain above $5 \mathrm{mg} / \mathrm{L}$ nearly all the time, assuming periods of much higher concentrations (APHA 1989). For short periods, concentrations as low as $4 \mathrm{mg} / \mathrm{L}$ can be tolerated (Welch 1980).

In the San Francisco Bay area, average dissolved oxygen concentrations of water samples collected within 3 feet of the bottom at selected dredge and disposal areas ranged from $6.6 \mathrm{mg} / \mathrm{L}$ to $10.1 \mathrm{mg} / \mathrm{L}$ (USACE 1975a). During dredging and disposal operations, concentrations may be reduced 1-2 mg/L but typically return to ambient levels within 4-8 minutes (USACE 1977).

\section{Toxicity of Sediment-Associated Trace Contaminants}

Chemistry-based assessments

Chemistry-based assessments of sediment toxicity often attempt to correlate observations of sediment toxicity with concentrations of sedimentassociated trace contaminants (e.g., Chapman et al. 1987, McGreer 1979). Once these correlations have been constructed, the toxicity of "unknown" sediment samples can presumably be inferred based on bulk chemistry. However, even if a significant correlations are observed, it does not mean a causal relationship has been established. That is, correlation does not mean causation.

Projecting cause and effect relationships based on an inventory of sediment chemistry ignores several important phenomena. Natural sediments typically contain a smorgasbord of contaminants; some known, some unknown and some extremely difficult to detect analytically. This is especially true for 
sediments from highly industrialized waterways such as the Oakland Harbor area. Sediments from these locations contain hundreds and perhaps thousands of anthropogenic and natural substances. Chemistry-based approaches typically account for only a small portion of trace contaminants actually present. They also do not account for any contaminant-contaminant interactions. The biological effects of chemicals acting synergistically would be underestimated in a chemistry-based approach. Also, variations in contaminant activity (e.g., bioavailability) are ignored in chemistry-based approaches. The same contaminant concentration in sediment with a high or low total organic carbon content will represent quite different mobility potentials.

In summary, chemistry-based approaches to evaluating sediment toxicity ignore underlying processes. Broad assumptions are necessary to infer toxicity based solely on sediment chemistry. The possibility that these assumptions are routinely violated and the existence of undetected covarying parameters raised concerns regarding the use and misuse of chemistry-based approaches in a regulatory environment (Spies 1989).

One way to avoid the problems associated with a chemical-by-chemical approach is to consider the contaminated sediment as a single entity. In other words, assess the aggregate effects (synergistic and antagonistic) of all its chemical constituents (detected and undetected) through the use of bioassays. This is, in fact, the approach (see below) taken in most regulatory programs charged with evaluating the potential biological impact of complex mixtures.

Surrogate toxicological bioassay approach

In the USACE's regulatory program, the potential toxicity of dredged material is determined via the surrogate toxicological bioassay approach. Briefly, representative samples of the sediment to be dredged are collected and brought into the laboratory. Appropriate sensitive test species are exposed to these sediments and a biological endpoint is monitored. The operative null hypothesis is there is no significant difference between the biological response in test sediment relative to a reference sediment from the disposal site environs. The statistical and experimental designs are constructed such that the observed biological response can be attributed solely to the test sediment.

It's important to remember that the surrogate toxicological bioassay approach is not intended to predict environmental impacts per se. Rather, it is intended to assess the potential for unacceptable adverse impacts by 
utilizing worst-case laboratory exposures and appropriate sensitive test organisms. The effectiveness of this regulatory approach is ultimately determined via a sound monitoring program which includes an evaluation of 1 ) the fate of contaminants in biota and 2) the viability of the biological community which may be impacted.

Sediment bioassays utilized in the USACE's regulatory program represent a balance between the state-of-the-art and what can be routinely carried out. Appropriate sensitive test animals for marine and estuarine sediments include amphipods (Rhepoxynius sp., Ampelisca sp.) and polychaetes (Neanthes sp., Nereis sp.) for solid phase bioassays and zooplankton (Acartia sp., larval crustaceans/bivalves), mysids (Mysidopsis sp., Neomysis sp.) and fish (Menidia sp., Cymatogaster sp.) for suspended sediment bioassays. Duration may range from 4 to 10 days. Percent survival is the most common and least ambiguous biological response monitored in sediment bioassays.

Acute toxicity bioassays

Acute toxicity bioassays for San Francisco Bay sediments were first included in the evaluative procedures specified in PN 78-1. Since most dredged material relocation sites were considered dispersive the elutriate procedure was followed. The tiered testing scenario called for acute toxicity bioassays if elutriate chemistry values exceeded state criteria or concentrations in disposal site material after allowance for the permissible mixing zone. Since project material rarely exceeded these comparisons elutriate bioassays were seldom conducted.

After shoaling was discovered near Alcatraz in 1982 the concept of fully dispersive disposal sites in San Francisco Bay was seriously questioned. That, in turn, renewed interest in the potential impacts of consolidated bedded sediments on benthic organisms. This interest is reflected in PN 87-1, issued jointly by CESPN, RWQCB and USEPA Region IX, which states, "It is now generally believed that if dredged material is going to have an environmental impact upon the disposal site, it will be upon the benthic environment." A similar conclusion was reached at the completion of the DMRP (Saucier et al. 1978).

Acute toxicity bioassays following procedures described in PN 87-1 were conducted on sediments from Oakland Inner Harbor (Word et al. 1988). This dataset probably represent the most extensive collection of bioassays conducted for the regulatory evaluation of San Francisco Bay sediments. During 10-day solid phase bioassays, four invertebrates species were exposed to 
18 Oakland Inner Harbor sediments and two uncontaminated reference sediments; sandy material from Point Reyes, $C A$ and fine-grained material from Sequim Bay, WA. No significant mortalities were observed in any of the test sediments for three of the test species; the clam, Macoma nasuta, the polychaete worm, Nephtys caecoides or the amphipod, Grandidierella japonica.

Significant mortalities were observed in the amphipod, Rhepoxynius abronius, exposed to four of the Oakland Inner Harbor sediments. These statistical differences were detected when comparisons were made to the sandy Point Reyes reference sediment. When compared to the fine-grain Sequim Bay reference material, no statistically significant mortalities were detected.

$R$. abronius prefers well sorted sandy substrate and will experience some mortalities in uncontaminated fine-grain material (DeWitt et al. 1988). Consequently, the significant mortalities observed for $R$. abronius in the four Oakland Harbor sediments may be due to a combination of sediment-associated trace contaminants and the effects of fine-grain material.

Acute toxicity bioassays were also conducted with suspended sediments Oakland Inner Harbor (Word et al. 1988). Mysid shrimp, Acanthomysis sculpta, speckled sand dab, Citharichthys stigmaeus, and oyster larvae, Crassostrea gigas, were exposed for 2 to 10 days to suspended sediments from five sites within Oakland Inner Harbor. These sites were selected to represent the most toxic material in Oakland Harbor. Sequim Bay material was used as the reference. The hierarchy of interspecific sensitivity was oyster larvae $>$ juvenile sand dabs > mature mysids. Although mortalities were observed in four of the five sediment treatments, no unacceptable adverse impacts on the environment were predicted after the allowable mixing zone was considered.

The bioassays described above focused on the regulatory evaluation of sediment from a single waterway in San Francisco Bay. Chapman et a1. (1987) conducted acute toxicity bioassays on sediments from three locations within the Bay: Oakland Harbor, San Pablo Bay and Islais Waterways. Survival of the amphipod, Rhepoxynius abronius and reburial of the clam, Macoma balthica, were evaluated in solid phase bioassays while suspended sediment bioassays were conducted with the mussel larvae, Mytilus edulis. Two of the tests (mussel larvae and clam reburial) involved 48-hour exposures while the amphipod bioassay lasted ten days. Sediment from one station in the Islais Waterway resulted in reduced survival and avoidance behavior in $R$. abronius. Acute exposures with clams and mussels produced a more graded response across all stations. However, interpretation of the clam test was confounded by the fact 
that control values were medial to all the sediment treatments. In all three bioassays, sediment from the Islais Waterway appeared to be the most toxic. However, it is important to note that while anthropogenic contaminants were elevated in Islais Waterway sediment the concentration of hydrogen sulfide was also extremely high; mean $=540 \mathrm{mg} / \mathrm{kg}$. The concentration is about two orders of magnitude greater than the other San Francisco Bay locations.

Chronic toxicity bioassays

Chapman et al. (1987) also conducted a chronic sublethal sediment bioassay with the copepod Tigriopus californicus. Reproduction, measured as the total number of young produced, was evaluated in copepods exposed to suspended sediments for four weeks. As with the acute toxicity bioassays, sediment from the Islais Waterway appeared to be the most toxic although there were no significant differences in copepod reproduction. The effects of elevated hydrogen sulfide concentrations in Islais Waterways sediments may have affected the observed response in copepod reproduction.

A number of field observations have been reported which suggest that San Francisco Bay biota may be experiencing chronic subletha1 stress. In contrast to the laboratory data discussed above (Word et al. 1988, Chapman et al. 1987), field observations have the advantage of examining organisms which have been chronically exposed under natural conditions. No lab to field extrapolation is necessary. The obvious disadvantage is that the direct link between biological response and sediment exposure is lost. The internal contaminant dose observed in field-collected animals may be acquired via ingested prey, bioconcentration from surrounding water as well as bioaccumulation from sediments. Consequently, the relationship between biological response and sediment exposure is equivocal.

One of the more intriguing observations on field-collected San Francisco Bay organisms is the relationship between mixed-function oxidase (MFO) activity and fertilization success in the starry flounder, Platichthys stellatus (Spies et al. 1988, Spies and Rice 1988). The MFO system is an enzyme complex embedded in the smooth endoplasmic reticulum of most organisms. It is involved in the detoxification of xenobiotics as well as the metabolism of lipids such as gonadotropic hormones. Spies and his colleagues found elevated MFO activities were inversely related to in vitro fertilization success and positively related to tissue concentrations of polychlorinated biphenyls. These results suggest that flounders in the San Francisco Bay area are experiencing chronic contaminant-related stress. 
A number of basic research questions remain, however, regarding the relationship between MFO activity and fertilization success in the starry flounder, $P$. stellatus. For example, the causality between induction and contaminant dose must be established via carefully designed laboratory experiments. Also, the numerical variability associated with the MFo inductionfertilization success relationship is very large. To have predictive ability, this variability must be diminished or at least its underlying causes identified. The quantitative importance of reduced fertilization success with respect to flounder population dynamics is not well understood (Spies et al. 1985). This guidance must be forthcoming before the data on fertilization rates can be fully interpreted. Finally, although flounder are intimately associated with bottom sediments there are no data directly linking the observed effects with sediments-associated contaminants.

Chronic sublethal effects have been observed in the blue mussel, Mytilus, placed along a transect from the Golden Gate Bridge into South Bay (Martin et al. 1985). Reduced Scope for Growth (SFG) was inversely related to the spatial gradient of increasing contaminant tissue concentrations; especially heavy metals. SFG is an instantaneous measure of energy available to the organism after maintenance requirements have been met. An analogous term would be "discretionary income" in a household budget. There is a large body of evidence indicating that a reduced SFG will lead to diminished fecundity and reproductive success in Mytilus. Similar results were observed in Mytilus edulis following the disposal of contaminated dredged material in Central Long Island Sound on the east coast (Nelson et al. 1987).

In the San Francisco study, the link between sediments and reduced SFG cannot be established. Uncontrolled co-variables such as decreasing salinity which also occurred along the same spatial gradient limit interpretation of the significance of observed biological effects. The use of multiple species (M. californianus and $M$. edulis) introduces possible interspecific error. Finally, the comparison of data collected at disparate times of the year introduces potential seasonal bias and limits the interpretability of these data.

A considerable amount of basic and contaminant-related information has been reported for Macoma balthica, a deposite-feeding infaunal bivalve (Thompson and Nichols 1988). This is particularly true for the South Bay populations which has experienced considerable heavy metal contamination (Luoma and Phillips 1988). The population dynamics of Macoma has been 
positively correlated with increases and decreases in heavy metal inputs into the South Bay (Nichols and Thompson 1985). Laboratory and field observations indicated this bivalve can successfully adapt biochemically and physiologically to heavy metal perturbations although the upper bounds of this adaptation are currently unknown (Cain and Luoma 1985, Johansson et a1. 1986). Macoma sp. is frequently used as a test species in the regulatory evaluation of dredged material in San Francisco Bay.

It is obvious from the preceding discussion that information on the chronic toxicity of San Francisco sediments is not nearly as prevalent as data on acute toxicity. For the former, most of our insights are inferential and based almost exclusively on field observations. Procedures to assess the acute toxicity of sediment are well developed and our experience with them spans nearly 20 years. In contrast, the development of chronic sublethal sediment bioassays is an emerging technology. This holds true for the entire country as well as San Francisco Bay (Phillips 1987, Luoma and Phillips 1988). Current activities are, for the most part, still within the realm of the R\&D community. Much research remains to be done before these tests can exit that arena and be incorporated into regulatory programs.

That transition will not be easy for two primary reasons. One, regulatory science carries a burden not shared with its counterpart in the R\&D community. In both forums, the science must be technically sound. However, in the regulatory environment, when serious questions concerning technical validity are raised, repercussions are felt well beyond the technical arena. These impacts may be political, economic and/or legal. When similar technical questions are raised in the R\&D community, (primarily through the peer-review process), discussions generally remain within the technical arena. Thus, regulatory science must be able to sustain technical as well as economic and judicial review.

The transition of chronic sublethal sediment bioassays from the R\&D community into regulatory programs will have to follow a deliberate pace simply because considerable development is required. It would be a grievous error to assume that chronic sublethal bioassays are merely acute toxicity bioassays of longer duration. There are significant and substantial issues which must be resolved prior to using any chronic sublethal test in a regulatory setting. Some of these issues are discussed in the following section. 


\section{PART III: DEVELOPMENT OF CHRONIC SUBLETHAL SEDIMENT BIOASSAYS}

\section{Rationale}

There are several reasons for evaluating the chronic sublethal effects of sediment on aquatic biota. The primary reason is that exposures to sediment-associated trace contaminants is likely to be chronic. Many contaminants of concern associate very closely with particulate material in the aquatic environment. The physico-chemical reasons for this partitioning behavior include hydrophobicity as well as ionic bonding. The net effect is bioaccumulation from a sediment matrix is a slow (i.e., chronic) process relative to bioconcentration from aqueous solution. Consequently, any potential biological effects will be the result of chronic exposures.

Assessment of chronic sublethal effects will more closely simulates what may actually be happening in the environment. Current bioassays are acute lethality tests. While they represent a worst case exposure scenario and utilize appropriate sensitive test organisms, they do not closely simulate actual exposure conditions.

Another reason for developing chronic sublethal sediment bioassays is that some compounds, such as PCBs (USEPA 1980, are simply not acutely toxic to aquatic organisms. They exert their biological effects only after prolonged, chronic exposures (see next section). Others contaminants of concern, such as polycyclic aromatic hydrocarbons (PAHs), require biotransformation prior to exerting any toxic effects (Varanasi 1989). These effects are often subtle sublethal responses; not overt lethality.

Finally, there is a regulatory mandate. The use of chronic or sublethal bioassays for the regulatory evaluation of dredged material is consistent with applicable Federal regulations under. Section 404 of Clean Water Act as amended and Section 103 of Marine Protection Research and Sanctuary Act as amended. Although an increasing number of investigators are examining the chronic sublethal effects of contaminated sediments, technically sound test protocols have not been sufficiently developed to a point where they can exit the R\&D community and be utilized in the regulatory environment. 


\section{Definition of Chronic}

Precisely what does the term "chronic" mean? Its Greek root word, "chronos," simply means "time." In the vernacular, chronic has come to mean "long time." Since acute toxicity tests typically range from 4-10 days one may imply a chronic sediment test is longer than 10 days.

However, since the term is used to describe a type of bioassay, it more appropriate to define chronic in biological terms. Certainly, a sediment exposure which persists for the entire life of an organism would be considered chronic. Chapman (1989), in fact, proposes that only full life cycle exposures be classified as chronic. The cynic would define chronic as one day longer than the exposure that was employed. At this point, it may be better to leave the definition imprecise and be descriptive when referring to an individual test method (e.g., 21-day growth bioassay).

Although the terms "chronic" and "sublethal" are often used to together, they are not interchangeable. The former connotes time only while the latter refers to any biological response other than lethality. It is perfectly correct, for example, to speak of "chronic lethal effects," or "acute sublethal effects." The terms "chronic" and "sublethal" are often juxtaposed because aquatic organisms will commonly survive chronic low level exposure but respond/adapt in some detectable manner.

\section{Potential Bias from Nontreatment Effects}

Chronic sublethal bioassays, as the name implies, measure endpoints which are affected prior to death. As such, they are often more sensitive than bioassays which measure lethality. Greater sensitivity, however, is a double-edged sword. It renders sublethal tests more susceptible to experimental artifacts. These artifacts, or nontreatment effects, often bias test results unknowingly. They can confound interpretation even in acute toxicity bioassays where percent survival is the end point. Important nontreatment effects include intraspecific density, inadequate food ration, suboptimal water quality, a change in the health and viability of the test species and the physical impacts of sediment.

Experimental bias due to this latter nontreatment effect have been documented for two sediment bioassays: the suspended particulate bivalve larvae test and the solid phase acute toxicity bioassay with the amphipod Rhepoxynius 
abronius. In the former, the physical effects of suspended sediment can have a significant detrimental effect on larval survival and normal development (Cardwell et al. 1976). In addition, the condition of the adult bivalves from which gametes are taken to initiate this test can have a major influence on test results (Cardwell et al. 1977). R. abronius normally inhabits well sorted sandy substrates. Placing it in fine-grained sediment is stressful and results in mortality unrelated to sediment contaminants (DeWitt et al. 1988). This can be especially problematic in the regulatory evaluation of dredged material since fine-grained sediment is characteristic of many inland waterways where environmental contaminants are often found.

\section{Selection of Test Species}

The primary criteria for selecting a test species are ecological importance and relative sensitivity to sediment contamination. For acute toxicity bioassays, where lethality is the endpoint, very sensitive animals are highly desirable (see Acute toxicity bioassays, p 18). For chronic sublethal sediment bioassays, it is desirable that the test species survive exposure. Polychaetes, bivalves, oligochaetes and fish have been recommended as desirable species (Anderson et al. 1984, Nelson et al. 1987). Gentile et al. (1987) reported the chronic sublethal effects of contaminated dredged material on two crustaceans, Ampelisca abdita and Mysidopsis bahia. More recently, Johns and Ginn (1989) have suggested a chronic sublethal sediment bioassay with the polychaete, Neanthes arenaceodentata for the Puget Sound area.

It is also important that the test species be amenable to testing. This means that the animal must be readily available via field collections or from laboratory cultures. It should be able to be handled in the laboratory without extraordinary effort. It should also not be especially sensitive to nontreatment effects (see previous section). Species selection may also be restricted by the biological endpoint of interest. For example, evaluating reproductive effects is particularly difficult in animals which have a planktonic larval stage. On the other hand, some measure of growth (i.e., a change in mass and/or physical dimension) is easily measured in most organisms. 


\section{Selection of Biological Endpoint}

Most sediment bioassays conducted for the regulatory evaluation of dredged material measure percent survival as the end point. One reason for this is percent survival is quantal; that is, an animal is either dead or alive at the end of the test. This facilitates quantification of results. It also facilitates interpretation of results. The biological importance of survival (or lack thereof) is unequivocal.

In contrast to survival, there is a plethora of sublethal endpoints which may be selected. These sublethal end points can be grouped according to level of biological organization (Figure 1). In order of increasing complexity these levels are: molecular, cellular, tissue, organismic (whole animal), populations and communities. When a perturbation (natural or contaminantinduced) occurs at any one level of biological organization, mechanistic explanations are generally found below the level of perturbation while ecological implications are found at higher levels of complexity (Bayne 1985).

In the aquatic environment, a primary concern is the maintenance of healthy, viable populations of organisms which are ecologically and/or economically important. Forecasting potential impacts at this level of biological organization is problematic and the predictive capabilities are not well developed. This is particularly true for benthic communities in a physically active system such as San Francisco Bay (Nichols 1985, Phillips 1987, Wright and Phillips 1988). Bioassessments at lower levels of complexity (molecularbiochemical) are often very sensitive, but their ecological relevance is uncertain. For these reasons, the surrogate toxicological bioassay approach (see earlier discussion) utilizing organismic end points is often adopted (Chapman 1983, Capuzzo et al. 1988). Examining whole animal response represents a propitious balance between the sensitivity of the endpoint and the ecological relevance of the experimental results (Figure 1). It is also logistically attractive approach from a regulatory perspective since most contract and research facilities in the United States are capable of conducting whole animal bioassays.

Because the surrogate toxicological bioassay approach extrapolates from laboratory observations on whole animals to potential impacts on populations in the wild, chronic effects on growth and reproduction are highly desirable sublethal endpoints (Bayne et al. 1980). These endpoints have the added benefit of being understood by the general public. This important characteristic 


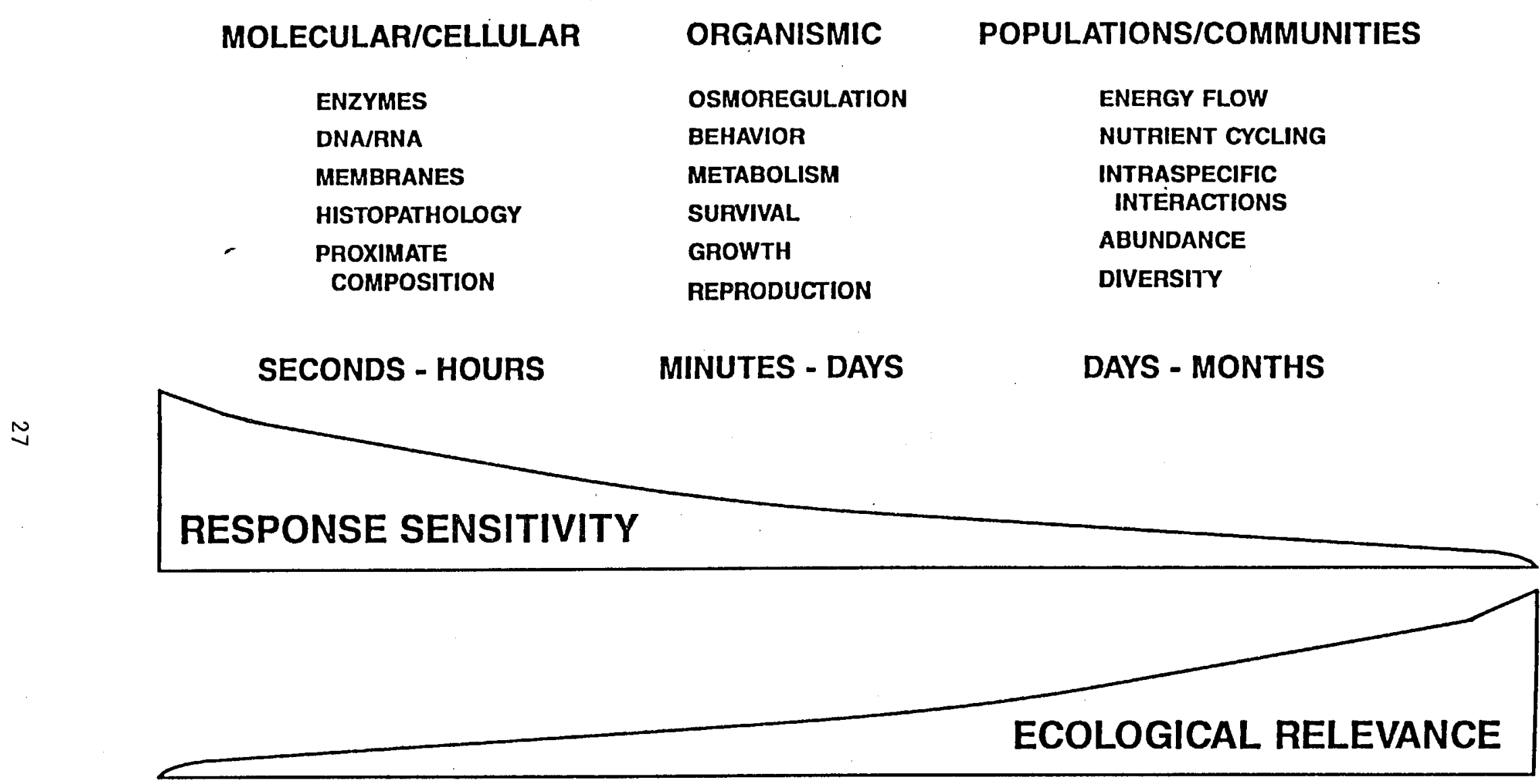

Figure 1. Sublethal endpoints within levels of biological organizations 
facilitates the communication of technical findings to a nontechnical audience.

\section{Development of Interpretive Guidance}

As noted above, most sediment bioassays conducted for regulatory purposes examine percent survival. The interpretation of these bioassays is relatively straightforward since the results are essentially binary; that is, the test animal either survived or it died. Mortality represents a clear, albeit severe, adverse environmental impact.

Chronic or sublethal effects, however, are more enigmatic. One reason they are difficult to assess is the fact that most fish and aquatic invertebrates are poikilothermic (Prosser 1973). That is, when variations in the external environmental occur their internal milieu also changes. The animal adapts to this change by utilizing a variety of interactive physiological and biochemical strategies. This adaptive response, or enantiostasis (Mangum and Towle 1977), ordinarily results in the establishment of a new physiological steady-state. The enantiostatic response contrasts sharply with the typical mammalian response which is to maintain a constant internal steady-state (homeostasis). Minor deviations from homeostasis (e.g., pH) can be pathological or even lethal. Therefore, because "change" is a normal characteristic in the physiology of fish and aquatic invertebrates, it is inappropriate to allege biological harm simply because a "change" has been observed.

So how does one interpret sublethal responses in these organisms which have been chronically exposed to contaminated sediment? This question has been addressed by others investigators evaluating the general response of biota to environmental perturbations. Basically, all their answers are adaptations of the concept of mammalian stress originally developed by Selye (1952). He defined stress in mammals as "a state of non-specific tension in living matter, which manifests itself by tangible morphologic changes in various organs and particularly in the endocrine glands which are under anterior pituitary control." The manifestation of stress in mammals is the General Adaptation Syndrome known coloquially as the "fight or flight" response. Clearly, this concept of stress is not appropriate for aquatic organisms which do not maintain homeostasis and who are morphologically dissimilar from mammals. 
Brett (1958) offered the following definition of stress based on his work with vertebrate poikilotherms (i.e., fish); "a state produced by any environmental or other factor which extends the adaptive responses of an animal beyond the normal range, or which distrubs the normal functioning to such an extent that, in either case, the chances of survival are significantly reduced." The key in this definition is the phrase "chances of survival are significantly reduced." Unless the change observed in the test species can be strongly linked to a decrease in survival potential, the change cannot be considered stressful. Thus, this definition for stress allows one to discriminate a mere "change" from a biologically important "effect." It also allows one to quantitate stress experimentally by measuring the degree to which survival potential is diminished.

If one interprets Brett's definition literally, it is applicable only when survival is being measured. Bayne (1975) enlarged on Brett's concept of survival potential with his definition of stress in marine invertebrates; "stress is a measurable alteration of a physiological (or behavioural, or biochemical, or cytological) steady-state which is induced by an environmental change, and which renders the individual (or the population, or the community) more vulnerable to further environmental change."

Definitions by Brett and Bayne suggest a common thesis for interpreting chronic or sublethal effects of contaminated sediment on aquatic organisms. That is, a change in any sublethal end point is insufficient to connote stress or biological harm. There must be a clear, quantifiable demonstration that change confers some disadvantage to the individual. 


\title{
PART IV: CONCLUSIONS
}

\author{
What Is Known
}

In conclusion, we can state that the following is known with a high degree of certainty.

1) San Francisco Bay is a high energy estuary which has undergone substantial physical alterations as a result of man's activities.

2) The benthic community in San Francisco Bay is diverse, temporally dynamic and inhabited by a large proportion of introduced species.

3) San Francisco Bay receives considerable contaminant input from point and non-point sources.

4) San Francisco Bay receives approximately 8-10.5 million cubic yards of sediment each year.

5) Contaminants of concern tend to associate with sediments.

6) Approximately 7 million cubic yards of sediment is dredged and relocated within the Bay each year.

7) Approximately 160-170 million cubic yards of sediment is naturally resuspended in the Bay each year by winds, tides and currents.

8) Ten years of evaluating dredged material with the USEPA/USACE elutriate procedures indicates little or no potential for unacceptable environmental impacts associated with dredging and relocation operations.

9) The potential toxicity of ammonia, sulfides and hypoxia during disposal operations is low because deviations from background are small and ephemeral.

10) Chemistry-based assessments of sediment toxicity cannot account for important phenomenon such as contaminant interactions, variations in contaminant activity (e.g., bioavailability) or the potential effects of chemically undetected chemicals.

11) There is a nationally accepted, technically sound Tiered Testing strategy for evaluating sediment toxicity.

12) There are nationally accepted, technically sound laboratory test procedures for determining the acute toxicity of sediments.

13) The surrogate toxicological bioassay approach is the most feasible, technically-sound strategy for the regulatory evaluation of dredged material toxicity.

14) There is a strong technical and regulatory rationale for evaluating the chronic sublethal effects of dredged material.

15) Growth and reproduction are highly desirable chronic sublethal end points. They are logistically attractive and results are understood by the general public.

16) Chronic sublethal testing of contaminated sediment is an emerging technology. It is receiving increased attention by private, state and 
Federal interests. At this point, the technology resides primarily in the R\&D community.

\section{What Is Not Known}

Likewise, we can conclude that the following are largely unknown or undeveloped technical issues.

1) The annual mass contribution of dredged material relocated within the Bay relative to the total amount of resuspended material.

2) The comparative biological effect of dredged material relocated within the Bay relative to the total amount of sediment resuspended each year.

3) The population and community level response to dredged material relocated within the Bay compared to the total amount of sediment resuspended each year.

4) The spatial extent of acutely toxic sediments in San Francisco Bay.

5) What constitutes a good reference sediment.

6) The comparative toxicity of bedded and suspended sediments from San Francisco Bay.

7) The chronic sublethal effects of San Francisco Bay sediments on fish and aquatic invertebrates.

8) Technically sound test procedures for evaluating chronic sublethal effects.

9) The influence of non-treatment effects on chronic sublethal responses.

10) How to interpret the technical results of chronic sublethal tests. 


\section{PART V: RECOMMENDATIONS}

Based on what is known and what technical issues remain to be resolved, the following recommendations are offered.

1) Adopt the tiered testing approach for evaluating sediment toxicity as jointly developed by USEPA and USACE for dredged material under Ocean Dumping Act.

2) Identify appropriate reference sediments and fully document selection rationales.

3) Develop technically sound test procedures for evaluating the chronic sublethal effects of bedded and suspended San Francisco Bay sediments.

4) Develop a biological monitoring plan to validate the efficacy of the regulatory testing program. The program's objective is to prevent unacceptable adverse impacts. Impacts include substantive changes in contaminant mobility and/or benthic community structure and function which can be directly attributed to disposal operations. Monitoring should emphasize chronic cumulative effects as opposed to short-term impacts of individual disposal operations. 


\section{Routine Regulatory Testing}

$\mathrm{H}_{01}$ : There is no significant difference(s) between the acute toxicity of project sediment(s) and reference sediment.

\section{Research}

$\mathrm{H}_{02}$ : There is no significant difference between the toxicity of bedded and suspended San Francisco Bay sediment.

$\mathrm{H}_{03}$ : There are no significant chronic sublethal effects of bedded San Francisco Bay sediments compared to an in-Bay reference sediment from the disposal site environs.

$\mathrm{H}_{04}$ : There are no significant chronic sublethal effects of suspended San Francisco Bay sediments compared to a representative in-Bay reference sediment.

$\mathrm{H}_{05}$ : There are no significant chronic sublethal effects of bedded San Francisco Bay sediments compared to an ocean reference sediment from the disposal site environs. 


\section{REFERENCES}

Adelman, I. R., and L. L. Smith. 1970. Effect of hydrogen sulfide on Northern Pike eggs and sac fry. Trans. Amer. Fish. Soc. 99:501-509.

Alabaster, J. S., D. G. Shurben and G. Knowles. 1979. The effect of dis solved oxygen and salinity on the toxicity of ammonia to smolts of salmon, Salmo salar L. J. Fish Biol. 15:705-712.

American Public Health Association. 1989. Standard methods for the Examination of Water and Wastewater, 17 th ed. American Public Health Association, American Water Works Association and Water Pollution Control Federation. Washington, DC.

Anderson, J., W. Birge, J. Gentile, J. Lake, J. Rogers, Jr. and R. Swartz. 1984. Biological effects, bioaccumulation, and ecotoxicology of sedimentassociated chemicals. Chapter 18 in K. L. Dickson, A. W. Maki and W. A. Brungs (eds.), Fate and Effects of Sediment-Bound Chemicals in Aquatic Systems, Pergamon Press, New York, pp 267-296.

Ankley, G. T., A. Katko, and J. W. Arthur. 1990. Identification of ammonia as an important sediment-associated toxicant in the lower Fox River and Green Bay, Wisconsin. Environ. Toxicol. Chem 9:313-322.

Arp, A. J., and Childress, J. J. 1983. Sulfide binding by the blood of the hydrothermal vent tube worm Riftia pachyptila. Science 219:295-297.

Baird, R., D. Wilson, and D. Miliken. 1973. Observations of Bregmaceros nectabanus Whitley in the anoxic, sulfurous water of the Cariaco Trench. Deep-Sea Res. 20:503-504.

Bayne, B. L. 1975. Aspects of physiological condition in Mytilus edulis L., with special reference to the effects of oxygen tension and salinity. Proceedings of the 9th European Marine Biology Symposium, pp 213-238.

Bayne, B. L. 1985. Cellular and physiological measures of pollution effect. Mar. Pollut. Bull. 16:127-128.

Bayne, B. L., J. Anderson, D. Engel, E. Gilfillan, D. Hoss, R. Lloyd, and F. P. Thurberg. 1980. Physiological techniques for measuring the biological effects of pollution in the sea. Rapports et Proces-Verbaux des Reunions Conseil International pour l'Exploration de la Mer 179:88-90.

Berner, R. 1963. Electrode studies of hydrogen sulfide in marine sediments. Geochim. et Cosmochim. Acta 27:563-575.

Boon, C. W., and B. J. Follis. 1967. Effects of hydrogen sulfide on channel catfish. Trans. Amer. Fish Soc. 96:31.

Brett, J. R. 1958. Implications and assessments of environmental stress, The Investigations of Fish Power Problems, H. R. MacMillan Lectures in Fisheries, Larkin, P. A., ed., pp 69-73.

Burrows, R. E. 1964. Effects of accumulated excretory products on hatchery reared salmonids. Bureau of Sport Fisheries and Wildlife Research Report $66: 1-11$.

Cain, D. J. and S. N. Luoma. 1986. Effect of seasonally changing tissue weight on trace metal concentrations in the bivalve (Macoma balthica) in San Francisco Bay. Mar. Ecol.-Prog. Ser. 28:209-217. 
Capuzzo, J. M., M. N. Moore and J. Widdows. 1988. Effects of toxic chemicals in the marine environment: Predictions of impacts from laboratory studies.

Aq. Toxicol. 11:303-311.

Cardwe11, R. D., C. E. Woelke, M. I. Carr and E. Sanborn. 1976. Sediment and elutriate toxicity to oyster larvae. Proceeding of the Speciality Conference on Dredging and its Environmental Effects, Mobile, AL, Jan 26-28, 1976.

Cardwe11, R. D., C. E. Woelke, M. I. Carr and E. Sanborn. 1977. Appraisal of a reference toxicant for estimating the quality of oyster larvae. Bul1. Environ. Contam. and Toxicol. 18:719-725.

Chapman, P. M. 1983. Do organisms in laboratory tests respond like organisms in nature? Aq. Toxicol. Hazard Assessm. Bishop, W. E., Cardwe11, R. D., and Heidolph, B. B. eds, ASTM STP 802, pp 315-327.

Chapman, P. M. 1989. A bioassay by any other name might not samell the same. Editorial in Environ. Toxico1. Chem. 8:551.

Chapman, P. M., R. N. Dexter and E. R. Long. 1987. Synoptic measures of sediment contamination, toxicity and infaunal community composition, (the Sediment Quality Triad) in San Francisco Bay. Mar. Ecol. - Prog. Ser. 37:7596.

Colby, P. V., and L. L. Smith. 1967. Survival of Walleye eggs and fry on paper fiber sludge deposits in Rainey River, Minn. Trans. Amer. Fish. Soc. $96: 278$.

Colt J., and G. Tchobanoglous. 1978. Chronic exposure of Channel Catfish, (Ictaluras punctatus). Prog. Fish Culturist 38:26-29.

Dewitt, T. H., G. R. Ditsworth and R. C. Swartz. 1988. Effects of natural sediment features on survival of the phoxocephalid amphipod Rhepoxynius abronius. Mar. Environ. Res. 25:99-124.

Dickson, K. L., A. W. Maki and W. A. Brungs. 1984. Fate and Effects of Sediment-Bound Chemicals in Aquatic Systems. Pergamon Press, New York, 449 pp.

Emerson, K., R. C. Russo, R. E. Lund and R. V. Thurston. 1975. Aqueous ammonia equilibrium calculations: Effect of $\mathrm{pH}$ and temperature. J. Fish. Res.

Bd. Can, 32:2379-2383.

European Inland Fisheries Advisory Commission. 1970. "Water Quality Criteria for European Fresh Water Fish: Report on Ammonia and Inland Fisheries," E.I.F.A.C. Technical Paper 11.

Gannon, J. E. and A. M. Beeton. 1971. Procedures for determining the effects of dredged sediments on biota-Benthos viability and sediment selectivity tests. J. Water Pollut. Control Fed. 43:392-398.

Gentile, J. H, K. J. Scott, S. M. Lussier and M. S. Redmond. 1987. The Assessment of Black Rock Harbor Dredged Material Impacts on Laboratory Population Responses. Technica1 Report D-87-3, US Army Engineer Waterways Experiment Station, Vicksburg, MS.

Howarth, R. W., A. Giblin, J. Gale, B. J. Peterson and G. W. Luther III. 1983. Reduced sulfur compounds in the pore waters of a New England saltmarsh, Environmental Blogeochemistry. Ecol. Bull. 35:135-152. 
Johansson, C., D. J. Cain and S. N. Luoma. 1986. Variability in the fractionation of $\mathrm{Cu}, \mathrm{Ag}$, and $\mathrm{Zn}$ among cytosolic proteins in the bivalve (Macoma balthica). Mar. Ecol. - Prog. Ser. 28:87-97.

Johns, D. M. and T. C. Ginn. 1989. Development of a Neanthes sediment bioassay for use in Puget Sound. US Environmental Protection Agency Puget Sound Estuary Program Report EPA 910/9-90-005, 57 pp.

Jones, R. A. and G. F. Lee. 1988. Toxicity of U. S, waterway sediments with particular reference to the New York Harbor area. Chemical and Biological Characterization of Sludges, Sediments, Dredge Spoils, and Drilling Muds, Lichtenberg, J. J., Winter, F. A., Weber, C. I., and L. Fradkins, eds., ASTM STP 976, pp 403-417.

Krone, R. B. 1979. Sedimentation in the San Francisco Bay System. In: San Francisco Bay: The Urbanized Esturary. T. J. Conomos (Ed). American Association for the Advancement of Science, San Francisco, CA, pp 85-96.

Lloyd, R. 1961. Effects of dissolved oxygen concentrations on the toxicity of several poisons to Rainbow Trout (Salmo gairdnerii: Richardson). J. Exp. Biol. 38:447-455.

Lloyd, R., and L. D. Orr. 1969. The diuretic response of Rainbow Trout to sublethal concentrations of ammonia. Water Res. 3:335-344.

Luoma, S. N. and D. J. H. Phillips. 1988. Distribution, variability, and impacts of trace elements in San Francisco Bay. Mar. Pollut. Bul1. 19:413425 .

Main, M. B. and W. G. Nelson. 1988. Tolerance of the sabellarid polychaete Phragmatopoma lapidosa Kinberg to burial, turbidity, and hydrogen sulfide. Mar. Environ. Res. 26:9-55.

Mangum, C. and D. Towle. 1977. Physiological adaptation to unstable environments. Amer. Sci. 65:67-75.

Martin, M., G. Ichikawa, J. Goetz1, D. de los Reyes and M. D. Stephenson. 1984. Relationships between physiological stress and trace toxic substances in the Bay Mussel, Mytilus edulis, from San Francisco Bay, California. Mar. Environ. Res. 11:91-110.

McGreer, E. R. 1979. Sublethal effects of heavy metal contaminated sediments on the bivalve Macoma balthica (L). Mar. Pollut. Bull. 10:259-262.

Merkens, J. C., and K. M. Downing. 1957. The effect of tension of dissolved oxygen on the toxicity of unionized ammonia to several species of fish.

Annals App1. Biol. 45:521-527.

Meyers, M. B., E. N. Powell and H. Fossing. 1988. Movement of oxybiotic and thiobiotic meiofauna in response to changes in pore-water oxygen and sulfide gradients around macroinfaunal tubes. Mar. Biol. 98:395-414.

Millero, F. J., T. Plese and M. Fernandez. 1988. The dissociation of hydrogen sulfide in seawater. Limnol. Oceanog. 33:269-274.

National Research Council, Division of Medical Science, Subcommittee on Hydrogen Sulfide. 1979. Hydrogen Sulfide, University Park Press, Baltimore, p 183 . 
Nelson, W. G., D. K. Phelps, W. B. Galloway, P. F. Rogerson and R. J. Pruell. 1987. Effects of Black Rock Harbor Dredged Material on the Scope for Growth of the Blue Musse1, Mytilus edulis, After Laboratory and Field Exposures. Technical Report D-87-7, US Army Engineer Waterways Experiment Station, Vicksburg, MS.

Nichols, F. H. 1985. Abundance fluctuations among benthic invertebrates in two Pacific estuaries. Estuaries 8:136-144.

Nichols, F. H., J. E. Cloern, S. N. Luoma, and D. H. Peterson. 1986. The modification of an estuary. Science 231:567-573.

Oseid, D., and L. Smith. 1974. Factors influencing acute toxicity estimates of hydrogen sulfide to freshwater invertebrates. Water Res. 8:739-746.

Pearson, T. H. and R. Rosenberg. 1978. Macrobenthic succession in relation to organic enrichment and pollution of the marine environment. Oceanog. Mar. Biol. Ann. Rev. 16:229-311.

Phillips, D. J. H. 1987. Toxic Contaminants in the San Francisco Bay - Delta and their Possible Biological Effects. Aquatic Habitat Institute Report, $413 \mathrm{pp}$.

Powe11, E. N., M. A. Crenshaw and R. M. Rieger. 1979. Adaptations to sulfide in the meiofauna of the sulfide system. I. ${ }^{35} \mathrm{~S}-\mathrm{Sulfide}$ accumulation and the presence of a sulfide detoxification system. J. Exper. Mar. Biol. Ecol. 37:57-76.

Powell, M. A., and G. N. Somero. 1983. Blood components prevent sulfide poisoning of respiration of the hydrothermal vent tube worm Riftia pachyptila. Science 219:297-299.

Prosser, C. L. 1973. Oxygen: Respiration and metabolism, Chapter 5 in Comparative Animal Physiology, Prosser C. L. (ed.), W. B. Saunders Company, Philadelphia, p 196.

Robinette, H. R. 1976. Effect of selected sublethal levels of ammonia on the growth of Channel Catfish (Ictaluras punctatus). Prog. Fish-Culturist 38:2629.

Saucier, R. T., C. C. Calhoun, Jr. and R. M. Engler. 1978. Executive Overview and Detailed Summary of the Dredged Material Research Program. Technical Report DS-78-22, US Army Engineer Waterways Experiment Station, Vicksburg, MS.

Selye, H. 1952. The Story of the Adaptation Syndrome, Act, Inc., Montreal, Canada, 225 pp.

Skarheim, H. P. 1973. Tables of the Fractions of Ammonia in the Undisassociated Form for $\mathrm{pH} 6$ to 9 , Temperature $0^{\circ}$ to $30^{\circ} \mathrm{C}$, TDS 0 to $3000 \mathrm{mg} / \mathrm{L}$ and Salinity 5 to $35 \mathrm{~g} / \mathrm{Kg}$, SERL Report No. 73-5, Sanitary Engineering Research

Laboratory, University of California, Berkley, CA, p 33.

Smart, G. 1976. The effect of ammonia exposure on gill structure of the Rainbow Trout (Salmo gairdnerii). J. Fish Biol. 8:471-475.

Smith, L. L. and D. M. Oseid. 1972. Effects of hydrogen sulfide on fish eggs and fry. Water Res. 6:711.

Smith, L., D. Oseid and L. 01son. 1976. Acute and chronic toxicity of hydrogen sulfide to the Fathead Minnow Pimephales promelas. Environ. Sci. Technol. 10:565-568. 
Spies, R. B. 1989. Sediment bioassays, chemical contaminants and benthic ecology: New insights of just muddy water? Editorial Mar. Environ. Res. $27: 73-75$.

Spies, R. B. and D. W. Rice., Jr. 1988. Effects of organic contaminants on reproduction of the starry flounder Platichthys stellatus in San Francisco Bay. II. Reproductive success of fish captured in San Francisco Bay and spawned in the laboratory. Mar. Biol. 98:191-200.

Spies, R. B., D. W. Rice, Jr. and J. Felton. 1988. Effects of organic contaminants on reproduction of the Starry Flounder Platichthys stellatus in San Francisco Bay I. Hepatic contamination and mixed-function oxidase (MFO) activity during the reproductive season. Mar. Biol. 98:181-189.

Spies, R. B., D. W. Rice, Jr., P. A. Montagna and R. R. Ireland. 1985. Reproductive success, xenobiotic contaminants and hepatic mixed-function oxidase (MFO) activity in Platichthys stellatus populations in San Francisco Bay. Mar. Environ. Res. 17:117-121.

Sousa, R. J. and T. L. Meade. 1977. The influence of ammonia on the oxygen delivery system of Coho Salmon hemoglobin. Comp. Biochem. Physiol. 58A:23-28.

Theede, H. 1973. Comparative studies on the influence of oxygen deficiency and hydrogen sulphide on marine bottom invertebrates. Neth. J. Sea Res. $7: 244-252$.

Theede, H., A. Ponat, K. Hiroki and C. Sclieper. 1969. Studies on the resistance of marine bottom invertebrates to oxygen deficiency and hydrogen sulphide. Mar. Bio1. 2:325-337.

Thompson, J. K. and F. H. Nichols. 1988. Food availability controls seasonal cycle of growth in Macoma balthica (L.) in San Francisco Bay, California. J. Exp. Mar. Biol. Ecol. 116:43-61.

Thurston, R. V., R. C. Russo and C. E. Smith. 1978. Acute toxicity of ammonia and nitrite to Cutthroat Trout Fry. Trans. Amer. Fish. Soc. 107:361367.

Thurston, R. V., R. C. Russo and G. A. Vinogradov. 1981a. Ammonia toxicity to fishes effects on $\mathrm{pH}$ on the toxicity of un-ionized ammonia species. Environ. Sci. Technol. 15:837-840.

Thurston, R. V., G. R. Phillips, R. C. Russo and S. M. Hinkins. $1981 \mathrm{~b}$. Increased toxicity of ammonia to Rainbow Trout (Salmo gairdnerii) resulting from reduced concentrations of dissolved oxygen. Can. J. Fish. Aq. Sci. $38: 983-988$.

Tomass.o, J. R., C. A. Goudie, B. A. Simco and K. B. Davis. 1980. Effects of environmental pH and calcium on ammonia toxicity in Channel Catfish. Trans. Amer. Fish. Soc. 109:229-234.

US Army Corps of Engineers. 1975a. Dredge Disposal Study, San Francisco Bay and Estuary; Appendix F: Crystalline Matrix Study. US Army Engineer District, San Francisco, San Francisco, CA.

US Army Corps of Engineers. 1975b. Dredge Disposal Study, San Francisco Bay and Estuary; Appendix G: Physical Impacts. US Army Engineer District, San Francisco, San Francisco, CA. 
US Army Corps of Engineers. 1975c. Dredge Disposal Study, San Francisco Bay and Estuary; Appendix H: Pollutant Uptake. US Army Engineer District, San Francisco, San Francisco, CA.

US Army Corps of Engineers. 1975d. Dredge Disposal Study, San Francisco Bay and Estuary; Appendix I: Pollutant Availability. US Army Engineer District, San Francisco, San Francisco, CA.

US Army Corps of Engineers. 1977. Dredge Disposal Study, San Francisco Bay and Estuary; Main Report. US Army Engineer District, San Francisco, San Francisco, CA.

US Army Corps of Engineers. 1979. Dredge Disposal Study, San Francisco Bay and Estuary; Appendix B: Pollutant Distribution. US Army Engineer District, San Francisco, San Francisco, CA.

US Environmental Protection Agency. 1976. "Quality Criteria For Water Sulfide - Hydrogen Sulfide," Office of Water and Hazardous Materials, Washington, DC, pp 213-215.

US Environmental Protection Agency. 1985. "Ambient Water Quality Criteria for Ammonia-1984," Office of Water Regulations and Standards Criteria and Standards Division, Washington, DC, p 217.

US Environmental Protection Agency. 1980. "Ambient Water Quality Criteria for Polychlorinated Biphenyls" Office of Water Regulations and Standards Criteria and Standards Division, Washington, DC, p 217.

US Environmental Protection Agency/US Army Corps of Engineers. 1977. Ecological Evaluation of Proposed Discharge of Dredged Material in Ocean Waters; Implementation Manual for Section 103 of PL 92-532 (Marine Protection, Research, and Sanctuaries Act of 1972).

Varanasi, U. 1989. Metabolism of Polycyclic Aromatic Hydrocarbons in the Aquatic Environment, U. Varanasi (ed.), CRC Press, Inc, Boca Raton, FL, $341 \mathrm{pp}$.

Vernberg, F. J., and W. B. Vernberg. 1970. The Animal and the Environment. Holt Rinehart and Winston, New York.

Welch, E. B. 1980. Ecological Effects of Waste Water, Chapter 12 in Fish, E. B. Welch (ed.), Cambridge University Press, New York, p 262.

Whitfield, M. 1974. The hydrolysis of ammonium ions in sea water - a theoretical study. J. Mar. Biol. Assoc. U.K. 54:565-580.

Word, J. Q., J. A. Ward, C. W. Apts, D. L. Woodruff, M. E. Barrows, V. I. Cullinan, J. L. Hyland and J. F. Campbe11. 1988. Coifirmatory sediment analyses and solid and suspended particulate phase bioassays on sediment from Oakland Inner harbor, San Francisco, California. Contract Report PNL-6794, Prepared by Battelle Pacific Northwest Laboratory for US Army Corps of Engineers, San Francisco District.

Wright, D. A. and D. J. Phillips. 1988. Chesapeake and San Francisco Bays: A study in contrasts and parallels. Mar. Pollut. Bull. 19:405-413.

Wuhrman, K. and H. Woker. 1948. Experimentelle untersuchenger uber die ammonik-und blausaurevergiftung. Schweizerische Zeitschrift fuer 11:210-244. 


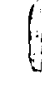

6 